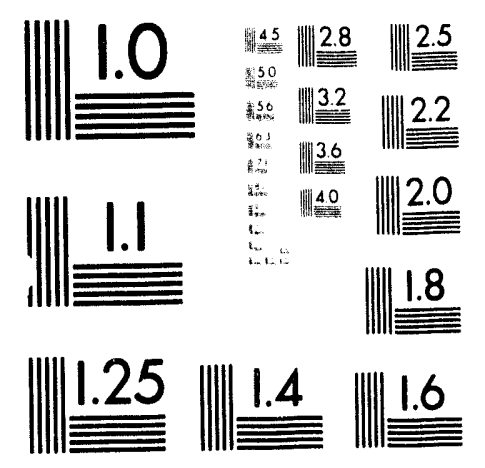



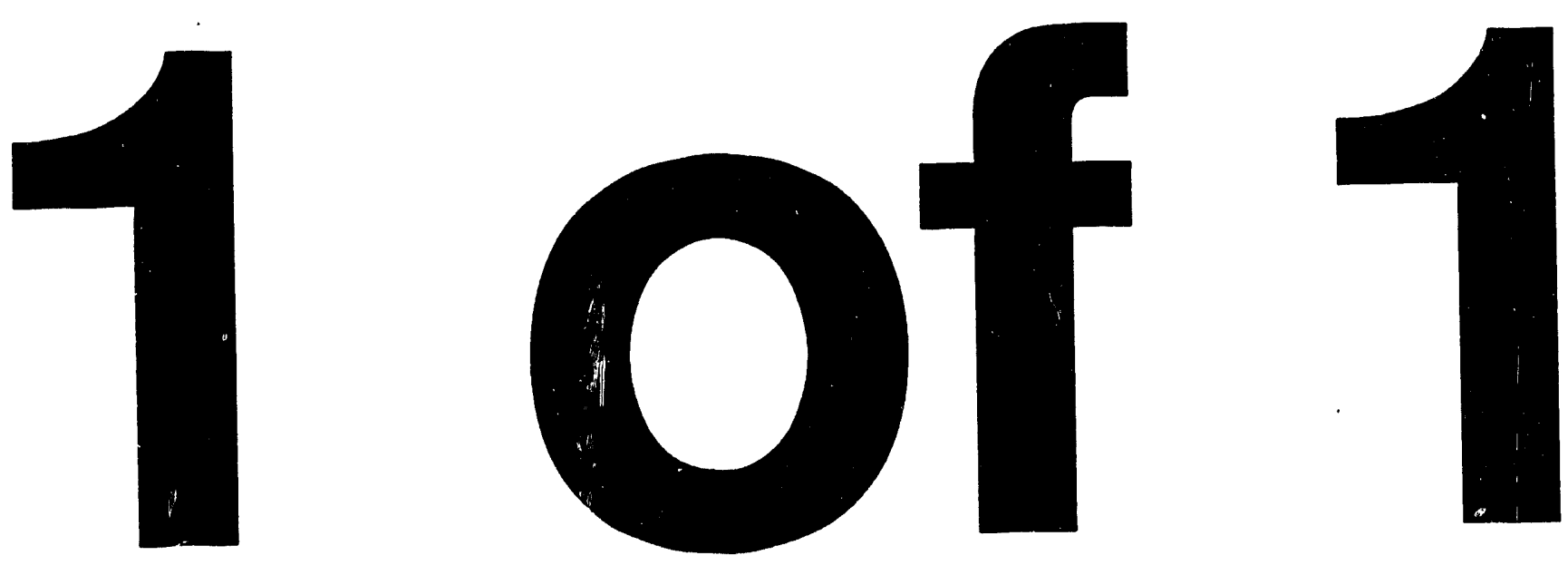
ES/ER/TM-90

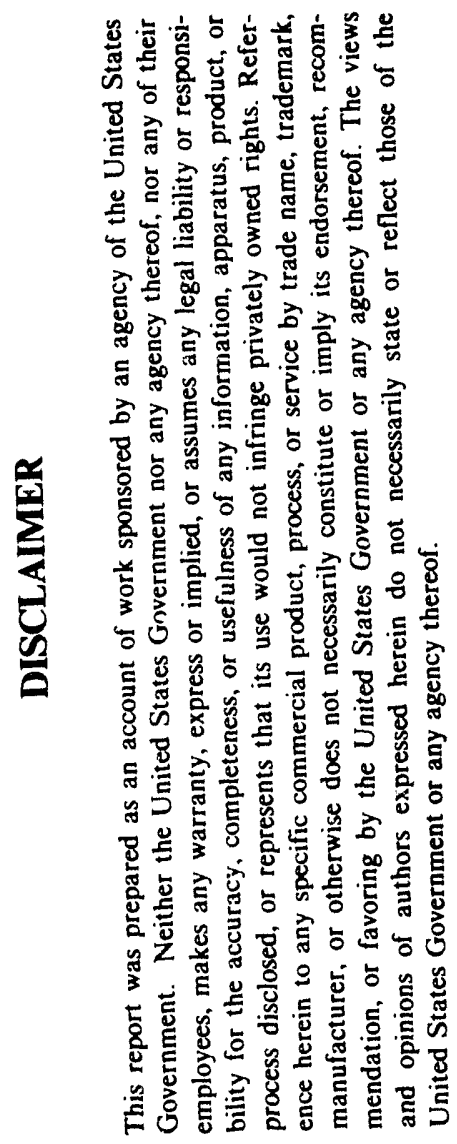

\title{
Environmental Restoration Program Pollution Prevention Checklist Guide for the Surveillance and Maintenance Project Phase
}

\author{
Environmental Restoration Division \\ P.O. Box 2003 \\ Oak Ridge, Tennessee 37831-7298
}

Date Issued-September 1993

Prepared for

U.S. Department of Energy

Office of Environmental Restoration and Waste Management under budget and reporting code EW 20

MARTIN MARIETTA ENERGY SYSTEMS, INC. managing the

Oak Ridge K-25 Site

Oak Ridge Y-12 Plant

Oak Ridge National Laboratory under contract DE-AC05-84OR21400
Paducah Gaseous Diffusion Plant Portsmouth Gaseous Diffusion Plant under contract DE-AC05-76OR00001

for the

U.S. DEPARTMENT OF ENERGY 


\section{CONTENTS}

ACRONYMS $\ldots \ldots \ldots \ldots \ldots \ldots \ldots \ldots \ldots \ldots \ldots \ldots \ldots \ldots \ldots \ldots \ldots \ldots$

1. PURPOSE $\ldots \ldots \ldots \ldots \ldots \ldots \ldots \ldots \ldots \ldots \ldots \ldots \ldots \ldots \ldots \ldots \ldots \ldots \ldots$

2. APPLICABILITY $\ldots \ldots \ldots \ldots \ldots \ldots \ldots \ldots \ldots \ldots \ldots \ldots \ldots \ldots \ldots \ldots$

3. INTRODUCTION $\ldots \ldots \ldots \ldots \ldots \ldots \ldots \ldots \ldots \ldots \ldots \ldots \ldots \ldots \ldots \ldots \ldots \ldots$

4. USE OF THYS CHECKLIST GUIDE FOR THE S\&M PROJECT ..... 2

5. INSTRUCTIONS FOR S\&M PROJECT PHASE USERS CHECKLIST .. 2

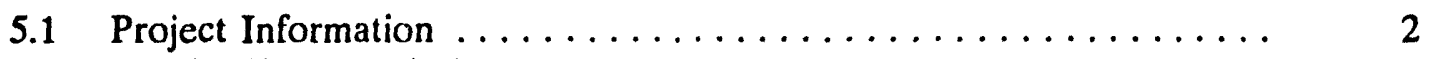

5.2 Facility/Site Description . . . . . . . . . . . .

5.3 General Question Information .................. 3

5.4 S\&M Phase-Specific Question Information $\ldots \ldots \ldots \ldots \ldots \ldots \ldots \ldots$

5.5 Waste Stream Information . . . . . . . . . . . . . .

6. BIBLIOGRAPHY $\ldots \ldots \ldots \ldots \ldots \ldots \ldots \ldots \ldots \ldots \ldots \ldots \ldots \ldots \ldots$

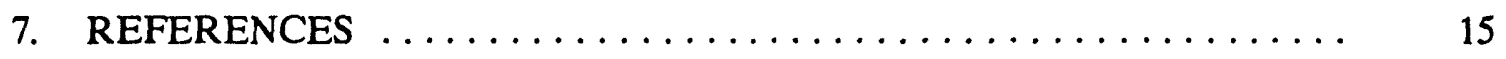

Figure 1 S\&M Project Phase Checklist $\ldots \ldots \ldots \ldots \ldots \ldots \ldots \ldots \ldots$ 


\section{ACRONYMS}

CAA Clean Air Act of 1970

CERCLA Comprehensive Environmental Response, Compensation, and Liability Act of 1980

EPA U.S. Environmental Protection Agency

ER Environmental Restoration

NPDES National Pollution Discharge Elimination System

OSHA Occupational Safety and Health Administration

PCB polychlorinated biphenyl

PPE personal protective equipment

PP/WM pollution prevention/waste minimization

RCRA Resource Conservation and Recovery Act of 1976

SARA Superfund Amendments and Reauthorization Act of 1986

S\&M surveillance and maintenance

WA waste assessment 


\section{PURPOSE}

DOE Order 5820.2 mandates that a surveillance and maintenance program be established in all shut-down facilities to ensure adequate containment of contamination, provide physical safety and security, and reduce potential public and environmental hazards. A key consideration in this process is the prevention of any waste to be generated from these activities.

The purpose of this checklist guide is to assist the user with incorporating pollution prevention/waste minimization (PP/WM) in all Surveillance and Maintenance (S\&M) phase projects of the Environmental Restoration (ER) Program. This guide will help users document their PP/WM activities for technology transfer and reporting requirements. Automated computer screens will be created from the checklist data to assist users with implementing and evaluating waste reduction. Users can then establish numerical performance measures to measure progress in planning, training, self-assessments, field implementation, documentation, and technology transfer. Cost savings result as users train and assess themselves and perform preliminary waste assessments.

\section{APPLICABILITY}

This checklist guide applies to all ER Program participants performing S\&M phase projects for all sources of pollution including air emissions, water, and solid waste. This guide is intended to serve three primary audiences:

- Site project managers and others on the project team engaged in activities focusing on or ultimately serving the process of incorporating PP/WM in the S\&M phase project;

- ER PP/WM specialists - for use as a general overview to help ensure that PP/WM criteria are being applied whenever possible in all S\&M phase projects; and

- ER Technology Development and Application specialists-for use as a tool for providing new and effective technology information to the site project managers.

Although this checklist guide may be used by a number of individuals as indicated above, it is incumbent on the ER Program to ensure that the projects select and apply technologies that not only result in the smallest quantities of waste with the least toxicity, but also minimize environmental releases during remediation. Minimizing waste generation should be considered in addition to the capital, maintenance, and operating costs to implement liabilities and any potential threat to human health and the environment. 


\section{INTRODUCTION}

This chapter identifies specific instances during the execution of a S\&M project where this guide may be helpful.

ER activities differ significantly from routine production facilities. While the focus for PP/WM for production operations is often on source reduction and recycling, those techniques are not readily adaptable to ER projects. Opportunities for source reduction and recycling are limited for clean-up activities since ER inherits contaminated waste sites from previous production processes, where ongoing process operations generally do not exist. Although treatment is not a preferred alternative per the U.S. Environmental Protection Agency (EPA) hierarchy, the nature of ER activities is generally such that clean up of the site by the application of some treatment technology is often the only alternative. The fact that the waste exists cannot be changed.

The success of incorporating PP/WM in the S\&M phase project will be determined ultimately by how successful the generator minimizes the volume and toxicity of the waste.

\section{USE OF THIS CHECKLIST GUIDE FOR THE S\&M PROJECT}

The document guide is organized into three sections. The first section of the checklist guide contains general questions concerning the generator's pollution prevention program in general. The second section of the checklist guide entails questions concerning the pollution prevention program as it applies to the S\&M project phase. The third section of the guide is more waste stream specific and contains questions concerning contaminants and media. The generator is also asked to give their rationale on how they would incorporate pollution prevention.

\section{INSTRUCTIONS FOR S\&M PROJECT PHASE USERS CHECKLIST}

The following are steps use to simplify this guide.

\subsection{PROJECT INFORMATION}

Complete the project information as requested in Sect. 1 of the S\&M Project Phase Checklist (Fig. 1, p. 4). 


\subsection{FACILITYYSITE DESCRIPTION}

Complete the facility/site description as requested in Sect. 1 of the S\&M Project Phase Checklist (Fig. 1).

\subsection{GENERAL QUESTION INFORMATION}

Complete the general questions as requested in Sect. 1 of the S\&M Project Phase Checklist (Fig. 1).

\subsection{S\&M PHASE-SPECIFIC QUESTION INFORMATION}

Complete the general S\&M project phase questions as requested in Sect. 2 of the S\&M Project Phase Checklist (Fig. 1).

\subsection{WASTE STREAM INFORMATION}

Complete the waste stream questions as requested in Sect. 3 of the S\&M Project Phase Checklist (Fig. 1). 
SECTION 1. GENERAL QUESTION INFORMATION

Project Name:

Project Manager:

Phase: S\&M

Project Location:

Facility/Site Description:

YES NO

1. Is there a PP/WM Site Plan on site?

2. Have the appropriate personnel been trained on:

- Site general employee radiation training?

- 24-hr SARA/OSHA (HAZWOPER) with 8-hr annual refresher?

- RCRA hazardous waste generator?

- Pollution prevention and waste minimization?

3. Does the PP/WM Site Plan have clear objectives and statcments of scope?

Does the PP/WM have numeric goals, scope, and objectives as follows:

- A statement of pollution prevention scope and objectives developed and distributed to all project personnel.

- A statement of pollution prevention scope and objectives developed and distributed to all contractor personnel.

- A statement of pollution prevention scope and objectives developed and distributed to all safety and emergency response personnel.

- Specific numerical goals for pollution prevention for each project waste stream set and distributed or displayed to all project personnel.

- Specific numerical goals for pollution prevention for each project waste stream set and distributed or displayed to all contractor personnel.

- Specific numerical goals for pollution prevention for each project waste stream set and distributed or displayed to all safety and emergency personnel.

Fig. 1. S\&M Project Phase Chacklist. 
4. Have project managers or personnel initiated work and waste management plans for projects that are scheduled to start within 180 days or less from now?

- $\quad \mathrm{PP} / \mathrm{WM}$ incorporated in any of the project work and waste management plans.

- A section on PPNW incorporated in at least one of the project work and waste management plans.

- A section on PP/WM in all the project work and waste management plans.

- A section on PP/WM in all the project work and waste management plans. Each section discusses at least three techniques to reduce or prevent waste generation.

5. Do project managers or personnel have the following data relating to site operations and waste streams so that pollution prevention opportunities can be identified?

- Supply and distribution records (i.e., chemical inventory, chain of custody, and waste drum tracking)?

- Maintenance records (i.e., inspection and preventive maintenance, repair orders)?

- Supervision records (i.e., quality assurance audits, noncompliance, and persunnel records)?

- $\quad$ Required permits and recurds (i.e., CAA, NPDES, and RCRA monitoring, RCRA accumulations facility inventories and manifests, CERCLA reportable quantity relcase, and sample waste analyses)?

- PP/WM program documentation (i.e., all work and waste management plans for projects scheduled 180 days or less from now)?

- Design information (i.e., process now diagrams and material balances)?

- Environmental information and reporting (i.e., sample waste analyses, RCRA/Tennessee Annual Report, EPA Biannual Report, and Pollution Prevention Act Tri-Report)?

- Raw material site information (i.e., material safety data sheets, contractor data logs, site operating procedures, and project schedules and milestones)?

- Economic information (i.e., waste treatment, disposal, operating, maintenance, and departmental and pollution prevention implementation cosis)?

Fig. 1 (continuca) 
6. Have project managers or personnel had the PP/WM plan audited in the last 12 months?

Was the program audited in the following manner:

- A periodic schedule for audit of activities was made?

- The audit was performed by those who have direct responsibility for performing the activities being audited?

- The audit was performed by those who do not have direct responsibility for performing the activities being audited?

- The audit was always reviewed by responsible management?

- Follow-up action was always taken as a result of the audit?

7. Does project management/personnel have cost, schedule, and program contents specific to the PP/WM program activities?

What kind of waste accounting is performed:

- Are operating cost records kept?

- Are treatment cost records kept?

- Are disposal cost records kept?

- Are maintenance cost records kept?

- Are life-cycle cost records kept?

- Are costs to implement pollution prevention activities kept?

- Are real-time cost savings since PP/WM plan implementations kept?

8. Have project managers or personnel evaluated the PP/WM Program to the numerical goal criteria in the last 12 months?

Are the following criterion used to evaluate the pollution prevention program:

- Number of numerical goals achieved?

- Number of cost reductions achicved?

Fig. 1 (continued) 
- Number of noncompliances cited?

YES NO

- Number or noncompliances cilcd?

- Number of new technologies integrated?

- Number of noncompliances corrected?

9. Do project managers or personnel keep and organize records from $\mathrm{PP} / \mathrm{WM}$ activities for quality assurance purposes?

Are the records from PP/WM activities kept and organized in the following manner:

- Records furnish documentary evidence from all PP/WM activities kept and organized?

- Records are well-organized and are easy to assess?

- Records are protected against damage, detcriorations, or loss?

- Requirements and responsibilities for record transmittal, distribution, retention, maintenance, and dispositions are established and documented?

10. Is technology information available for comparison from other sites for PP/WM assessment?

11. Do facility managers or personnel implement mechanisms for quality improvement in PP/WM to prevent noncompliance?

How often does management assess the PP/WM Site Plan to ensure that it is adequate and is effectively implemented?

a. Never.

b. No regular schedule for assessing the PP/WM program; occasionally performed.

c. Regular schedule for assessing the PP/WM program; performed every 2 years.

d. Regular schedule for assessing the PP/WM program; performed every year.

e. Regular schedule for assessing the PP/WM program; performed at least every 6 months.

Fig. 1 (continued) 
SECTION 2 S\&M PHASE-SPECIFIC QUESTION INFORMATION

1. Is there an ER PP/WM Site Plan on site?

2. Is PP/WM currently incorporated in the S\&M documents?

3. Does the ER PP/WM Site Plan include specific quantitative goals for reducing the volume or toxicity of each waste stream?

4. If specific numerical goals are not included for each waste stream, is a strategy outlined to arrive at numerical goals?

5. Does the ER PP/WM Site Plan include programmatic goals for the evaluation of new technologies to reduce waste generation for $S \& M$ activities?

6. Does the ER PP/WM Site Plan contain a budget for its waste minimization program?

7. Is there a method for iracking waste for the ER site's waste management activities from the point of generation to the point of discharge or treatment, storage, or disposal?

8. Has the organization developed baseline data for the generation of waste?

9. Is there a method for accounting for waste management costs?

10. Has the organization developed guidance for applying quality assurance to waste minimization activities?

11. Does the ER PP/WM Site Plan explain how PP/WM principles are incorporated into activities involving S\&M?

12. Have ER PP/WM waste assessments (WAs) been conducted on the waste streams that have been generated?

13. If ER PP/WM WAs have not been conducted, are there plans to conduct WAs in this fiscal year?

14. Does the ER PP/WM Site Plan identify research and development projects related to $S \& M$ activities?

15. Does the ER PP/WM Site Plan describe technology transfer activities that are planned for S\&M activitics?

16. Does the ER PP/WM Site Plan describe a procedure for evaluating the S\&M PP/WM program?

17. Does the PP/WM Site Plan explain how design principles that minimize waste generation are incorporated into new construction and options that involve new or modilied processes?

Fig. 1 (continued) 


\section{SECTION 3. WASTE STREAM INFORMATION}

1. What are the contaminants on site? (Use additional pages if necessary.)

2. How are the contaminants stored or contained? (Use additional pages if necessary.)

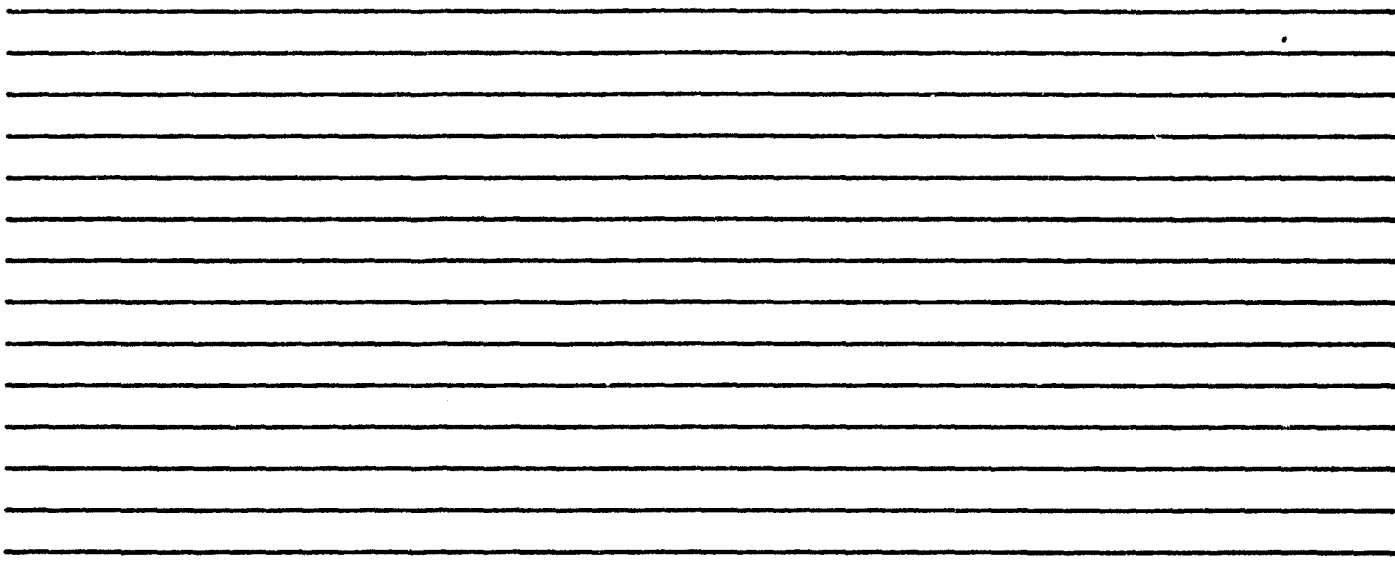

YES NO

3. Are the contaminants stored in a manner that reduces the generation of waste?

Are wastes always segregated at the source to minimize the generation of waste?

4. Is an effort made to separate clothing contaminated with a certain level of radioactive material from that contaminated with a lower level to make it possible to reuse that with the lower level following laundering?

5. Is clothing contaminated with radioactive material maintained separate from that not contaminated with radioactive matcrial?

6. Are hand, clothing, and foot monitors available near arcas containing radioactive material to reduce the potential for spread of such material?

Fig. 1 (continucd) 
7. Are the containers labeled properly with the following information:

- Proper name or shipping name?

- Start date for accumulation?

- Proper EPA code?

- Proper EPA facility identification number?

8. Is all documentation properly filed and retained for the appropriate length of time?

9. Do strict housekeeping requirements exist to minimize potential for cross contamination?

10. Before beginning a maintenance task, have the following items been assessed:

- Materials available from surplus stores?

- Necessary amount of materials to complete the job?

- Necessary amount of personal protective equipment (PPE) to complete the job?

- Removal of packaging before entering contaminated areas?

- Plastic floor covering to collect scrap (shavings, etc.) from the area?

11. During S\&M activities, do any methods exist that may unnecessarily generate waste (e.g., failing to use floor coverings for waste gencrated in polychlorinated biphenyl (PCB) areas; taking more material into a contaminated area than is necessary; failing to check surplus stores before beginning a task; or failing to remove packaging before entering a contaminated area)?

12. Is there an approved plan for periodic calibration of instruments used for surveillance of waste with regard to radiation level, constituent concentration, and other appropriate parameters?

If $\mathrm{so}_{\mathrm{o}}$ is it being implemented?

13. Is there an approved plan for preventative maintenance (e.g., lubrication, painting, and adjustments) of facilities lurned over to ER?

If so, is it being implemented?

14. Is there an exhaust system for enclosed areas containing piping and equipment that may leak gas or vapor?

Fig. 1 (continued) 
Are the exhaust system equipment and its filters inspected periodically for adequacy?

15. Are systems containing gas or material that may vaporize monitored for airborne release?

Is the monitoring continuous?

16. Have all pipelines and valves been included on the routine inspection checklists?

Are repairs made to the pipelines and valves in a manner that minimizes the generation of waste?

17. Have all drum storage areas been included on the routine inspection checklists?

Are drums clearly marked, in good repair, and stored in approved storage areas?

18. Do the drum storage areas provide adequate protection and containment for the waste and allow for easy inspection and decontamination?

Are repairs made to the drum storage areas in a manner that minimizes the generation of waste?

19. Have all B-25 box storage areas been included on the routine inspection checklists?

Are repairs made to the B-25 box storage areas in a manner that minimizes the generation of waste?

20. Has all secondary containment been included on the routine inspection checklists?

Are repairs made to the secondary containment in a manner that minimizes the generation of waste?

21. Have all cylinder storage yards been included on the routine inspection checklists?

Are repairs made to the cylinder storage yards in a manner that minimizes the generation of waste?

22. Have all cooling towers been included on the routine inspection checklis is?

Are repairs made to the cooling towers in a manner that minimizes the generation of wastc?

Fig. 1 (continuw) 
23. Can any primary waste streams be recycled or reused (e.g., unopened materials such as Liquid Nails, caulking, ctc.)?

24. Can any secondary waste streams be recycled or reused (e.g., opened materials such as paint)?

25. Can any of the solvents used be substituted with solvents less hazardous/toxic?

26. Can the frequency of "diaper" (absorbent material) changes for PCB leaks be lessened to reduce the volume of waste?

Can the size of the diapers used for PCB leaks be minimized to reduce volume of waste?

27. Is there proper selection of PPE?

Is only the necessary amount of PPE worn into a contaminated area?

Is the PPE used its maximum amount?

28. Do the following methods of pretreatment of waste exist:

- Compaction?

- Decontamination?

- Dewatering?

- Other (describe)?

29. Do any additional technologies exist that should be considered for PP/WM in the S\&M phase? Please describe.

Fig. 1 (continucd) 
30. Are there any additional ideas that should be considered for PP/WM in the S\&M phase? Please describe.

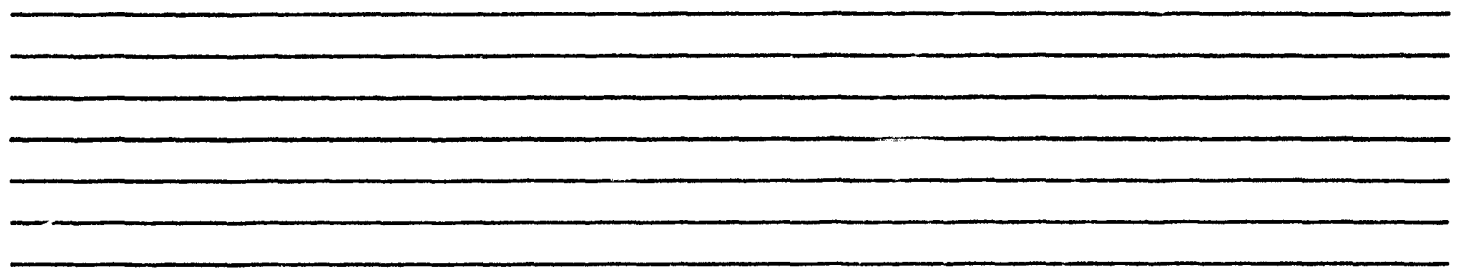

Fig. 1 (continucd) 


\section{BIBLIOGRAPHY}

Energy Systems (Martin Marietta Energy Systems, Inc.). 1993. Oak Ridge K-25 Site Technology Logic Diagram, Vol. 1: Technology Evaluation. K-2073, Oak Ridge K-25 Site, Oak Ridge, Tennessee, February.

Energy Systems. 1993. Oak Ridge K-25 Site Technology Logic Diagram, Vol 2: Technology Logic Diagrams. K-2073, Oak Ridge K-25 Site, Oak Ridge, Tennessee, February.

Energy Systems. 1993. Oak Ridge K-25 Site Technology Logic Diagram, Vol. 3, Part A: Characterization, Decorsamination, and Dismantlement. K-2073, Oak Ridge K-25 Site, Oak Ridge, Tennessee, February.

Energy Systems. 1993. Oak Ridge K-25 Site Technology Logic Diagram, Vol. 3, Part B: Remedial Action, Robotics/Automation, and Waste Management. K-2073, Oak Ridge K-25 Site, Oak. Ridge, Tennessee, February.

Energy Systems. 1993. Decontamination and Decommissioning Technology Assessment. DOE/OR-1051, Oak Ridge K-25 Site, Technical Division, Oak Ridge Tennessee, March. 


\section{REFERENCES}

Energy Systems (Martin Marietta Energy Systems, Inc.). 1991. "General Surveillance and Maintenance Procedure." Document Number 150.29, Oak Ridge K-25 Site, Oak Ridge, Tennessee, October. 


\title{
DISTRIBUTION
}

\author{
1. R.O Barnett \\ 2. D. T. Bell \\ 3. S.C. Bieniek \\ 4. H.L. Boston \\ 5. J. M. Cash \\ 6. C. Clark \\ 7. J. S. Colley \\ 8. K.W. Cook \\ 9. R. B. Cook \\ 10. S. L. Cross \\ 11. T. Dahl \\ 12. D.T. Davenport, PORTS \\ 13. M. F. P. DeLozier \\ 14. C. D. Goins \\ 15. J.T. Grumski \\ 16. P. J. Halsey \\ 17. T. C. Houk \\ 18. S. H. Howell \\ 19. G.L. Johnson \\ 20. R. K. Kibbe \\ 21-22. A. K. Lee/DOE-OSTI \\ 23. S. M. Leone \\ 24. J.C. Massey \\ 25.28. D. M. Matteo \\ 29-30. P. T. Owen \\ 31. G. A. Person \\ 32. B.E. Phifer, Jr. \\ 33. E.J. Powell \\ 34. A. S. Quist \\ 35. G. E. Rymer \\ 36. C.M. Smith \\ 37. P. C. Stumb \\ 38. J. S. Suffern \\ 39. A. E. Walzer \\ 40. D. R. Watkins \\ 41. R. K. White \\ 42. Central Research Library \\ 43-47. ER Document Management Center \\ 48. ORNL Laboratory Records
}

49-50. R. L. Nace, Branch Chief, Nonenrichment Facilities, Oak Ridge Program Division, Office of Eastern Area Programs, Office of Environmental Restoration, EM-423, Trevion 2, U.S. Department of Energy, Washington, DC 20585

51. R. C. Sleeman, DOE Oak Ridge Field Office, P.O. Box 2001, Oak Ridge, TN 37831.8541

52. D. W. Swindle, Radian Corporation, 120 South Jefferson Circle, Oak Ridge, TN 37830

53-54. H. M. Thron, Chief, Enrichment Facilitics, Oak Ridge Program Division, Office of Eastern Area Programs, Office of Environmental Restoration, EM-423, Trevion 2, U.S. Department of Energy, Washington, DC 20585

55. Office of Scientific and Technical Information, P.O. Box 62, Oak Ridge, TN 37831 

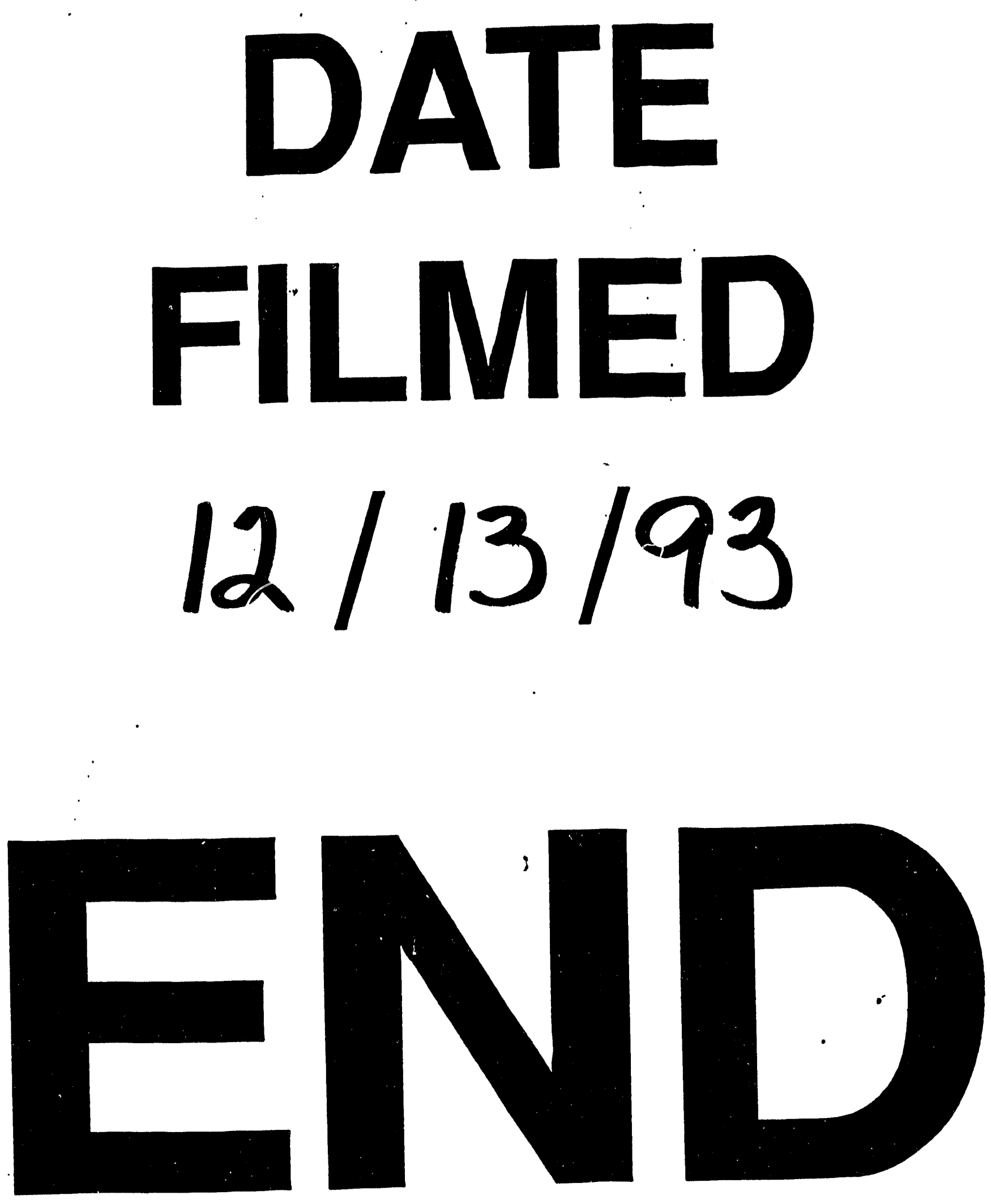
